\title{
Hypoglycaemia as the Result of Isolated Corticotrophin-deficiency
}

\author{
KENNETH A. WOEBER,* M.B., B.CH., M.R.C.P.ED.; RONALD ARKY,* M.D.
}

Brit. med. F., 1965, 2, 857-858

In the fasting state glucose homoeostasis is dependent on gluconeogenesis (Bondy, 1958). Consequently, disruption of gluconeogenesis by the ingestion of alcohol (Freinkel et al., 1963) or defective gluconeogenesis accompanying cortisol or growth-hormone deficiency may cause symptomatic hypoglycaemia.

The case to be reported is that of a middle-aged man who, over a period of two years, suffered six attacks of hypoglycaemia. In all instances these attacks occurred in the fasting state; alcohol-ingestion appeared to be a precipitating factor in the early attacks, but this could not be implicated in the later episodes. The studies that were subsequently carried out in this patient, as well as his response to treatment, indicated that a pituitary or hypothalamic defect affecting the secretion of corticotrophin alone was responsible for the hypoglycaemic tendency.

\section{Case Report}

A negro handyman aged 54 was admitted in an unresponsive state to the Boston City Hospital on three separate occasions between May 1960 and June 1961. On each admission the odour of alcohol was present on his breath, the blood glucose was found to be less than $20 \mathrm{mg} . / 100 \mathrm{ml}$., and a prompt response to the intravenous administration of glucose was obtained. A diagnosis of alcohol-induced hypoglycaemia was made. The patient was not seen again until June 1962, when he was admitted on two further occasions in an unresponsive state. On both admissions the blood glucose was found to be less than $20 \mathrm{mg} . / 100 \mathrm{ml}$. In contrast to the three earlier admissions, however, there was no evidence of recent alcohol ingestion, and this was confirmed by the absence of alcohol in the serum. He again responded promptly to glucose, but refused to remain in the hospital for diagnostic studies. One month later he was admitted to a psychiatric hospital because of bizarre behaviour. The blood glucose was found to be $24 \mathrm{mg}$./ $100 \mathrm{ml}$., but there was no evidence of recent alcohol ingestion. After treatment with glucose he was transferred to the Thorndike Metabolic Ward at the Boston City Hospital for diagnostic studies.

The patient had been a heavy drinker for at least 15 years. The earlier attacks of loss of consciousness followed bouts of heavy drinking. In contrast, his later attacks occurred after moderate exertion when he had not eaten for several hours. He had lost $18 \mathrm{lb}$. ( $8.1 \mathrm{~kg}$.) over the preceding two months, but denied change in skin colour, loss of libido, or symptoms of postural hypotension. To his knowledge no member of his immediate family had diabetes mellitus. He had not taken drugs at any time during his illness.

On examination he was an alert, thin, negro man. His weight was $120 \mathrm{lb} .(54 \mathrm{~kg}$.) and his height $5 \mathrm{ft} .6$ in. $(1.6 \mathrm{~m}$.). Pulse and blood-pressure were normal, and postural hypotension was absent. Skin and hair were normal; no increase in pigmentation was present. The heart, lungs, and abdomen were normal. There was no testicular atrophy. Rectal examination revealed an enlarged prostate gland. The nervous system, including examination of the visual fields, was normal.

Urinalysis and blood count were normal. Fasting blood glucose was $70 \mathrm{mg} . / 100 \mathrm{ml}$. and blood urea nitrogen $15 \mathrm{mg} . / 100 \mathrm{ml}$. Serum electrolytes were normal. Liver-function studies were as follows: bilirubin $0.7 \mathrm{mg} . / 100 \mathrm{ml}$., alkaline phosphatase 1.8 Bessie-

* Department of Medicine, Harvard Medical School, and Thorndike Memorial Laboratory, Boston City Hospital, Boston, Massachusetts, U.S.A.
Lowry units, albumin $4.3 \mathrm{~g} . / 100 \mathrm{ml}$, and cholesterol $252 \mathrm{mg} . /$ $100 \mathrm{ml}$; bromsulphthalein was not retained after 45 minutes. Radiograph of the chest was normal, and the Mantoux test was negative. Radiograph of the skull and examination of the cerebrospinal fluid were normal.

The Table summarizes the results of the studies that were carried out to evaluate endocrine function. Basal 24-hour urinary 17ketogenic steroids and 17-ketosteroids were consistently low, but an increase was observed after the intravenous administration of corticotrophin. In contrast, methopyrapone (metyrapone), which stimulates the secretion of endogenous corticotrophin by inhibiting cortisol synthesis (Liddle et al., 1958), had no effect on urinary steroid excretion. Studies of thyroid and gonadal function were normal. Plasma growth-hormone was demonstrable in the fasting state, and a normal increase was observed during insulin-induced hypoglycaemia.

\begin{tabular}{|c|c|c|}
\hline \multicolumn{3}{|c|}{ Studies of Endocrine Function } \\
\hline \multirow{3}{*}{$\begin{array}{l}\text { Urinary 17-ketogenic } \\
\text { steroids (Norymberski) }\end{array}$} & \multirow{2}{*}{$\begin{array}{l}\text { Control } \\
\text { Second day of A.C.T.H. } \\
(20 \text { units intravenously } \\
\text { over } 8 \text { hr. })\end{array}$} & $7 \cdot 1 \mathrm{mg} . / 24 \mathrm{hr}$. (normal = \\
\hline & & $24 \cdot 0 \mathrm{mg} \cdot / 24 \mathrm{hr}$ \\
\hline & $\begin{array}{l}\text { Control } \\
\text { Day after methopyrapone } \\
(250 \mathrm{mg} \text {. every } 2 \mathrm{hr} . \times 12)\end{array}$ & $\begin{array}{l}5 \cdot 1 \mathrm{mg} . / 24 \mathrm{hr} . \\
5 \cdot 1 \stackrel{y}{ }\end{array}$ \\
\hline \multirow[t]{3}{*}{$\begin{array}{l}\text { Urinary 17-ketosteroids } \\
\text { (Norymberski) }\end{array}$} & \multirow{2}{*}{$\begin{array}{l}\text { Control } \\
\text { Second day of A.C.T.H. } \\
(20 \text { units intravenously } \\
\text { over } 8 \text { hr. })\end{array}$} & $4 \cdot 3 \mathrm{mg} . / 24 \mathrm{hr}$. (normal $=$ \\
\hline & & $10.5 \mathrm{mg} . / 24 \mathrm{hr}$. \\
\hline & $\begin{array}{l}\text { Control } \\
\text { Day after methopyrapone } \\
(250 \mathrm{mg} \text {. every } 2 \mathrm{hr} . \times 12)\end{array}$ & 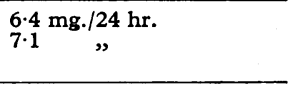 \\
\hline Plasma growth hormone* & $\begin{array}{l}\text { After overnight fast } \\
\text { During insulin hypo- } \\
\text { glycaemia }\end{array}$ & $<1 \mathrm{~m} \mu \mathrm{g} . / \mathrm{ml}$ \\
\hline \multicolumn{2}{|l|}{ Urinary F.S.H. } & Positive at 25 mouse units \\
\hline \multicolumn{2}{|l|}{$\begin{array}{l}\text { Thyroidal }{ }^{131} \text { I uptake at } \\
24 \mathrm{hr} \text {. }\end{array}$} & $\begin{array}{r}27 \% \text { of adm. dose } \\
(\text { normal }=15-45)\end{array}$ \\
\hline \multirow[t]{2}{*}{ Butanol-extractable iodine } & Before cortisone & \multirow{2}{*}{$\begin{array}{l}4.4 \mu \mathrm{g} . / 100 \mathrm{ml} \text {. (normal = } \\
4-6) \\
5.7 \mu \mathrm{g} . / 100 \mathrm{ml} .\end{array}$} \\
\hline & During " & \\
\hline $\begin{array}{l}\text { Fractional rate of thy- } \\
\text { roxine disposal }\end{array}$ & $\begin{array}{l}\text { Before cortisone } \\
\text { During } "\end{array}$ & $\begin{array}{l}8 \cdot 8 \pm 0.6 \% / 24 \mathrm{hr} . \\
10 \cdot 7 \pm 0.3 \% / 24 \mathrm{hr}\end{array}$ \\
\hline $\begin{array}{l}\text { Absolute rate of thyroxine } \\
\text { disposal }\end{array}$ & $\begin{array}{l}\text { Before cortisone } \\
\text { During },\end{array}$ & $\begin{array}{l}42.7 \mu \mathrm{g} . \text { iodine } / 24 \mathrm{hr} . \\
65.8 \mu \mathrm{g} \text {. iodine } / 24 \mathrm{hr} .\end{array}$ \\
\hline Basal oxygen consumption & $\begin{array}{l}\text { Before cortisone } \\
\text { During },\end{array}$ & $\begin{array}{l}147 \mathrm{ml} . / \mathrm{min} . \\
175 \mathrm{ml} . / \mathrm{min} .\end{array}$ \\
\hline
\end{tabular}

* Analyses performed by Dr. S. Glick, Bronx VA Hospital.

The Figure depicts the response of the blood-glucose concentration to the intravenous administration of $0.1 \mathrm{unit} / \mathrm{kg}$. of glucagonfree insulin; the hypoglycaemia-unresponsiveness was corrected by the simultaneous administration of corticotrophin.

During his stay in the hospital the patient developed frequency of micturition. Over the next two days he became increasingly anorectic and complained of cramps in his limbs. On the third day of his illness his temperature rose to $102^{\circ} \mathrm{F}$. $\left(38.9^{\circ} \mathrm{C}.\right)$, and profuse vomiting and diarrhoea occurred. $\mathrm{He}$ was mildly dehydrated; the pulse was rapid and of poor volume, and the blood-pressure was $74 / 40 \mathrm{~mm}$. Hg. Both costovertebral angles were tender. A diagnosis of acute hypoadrenocorticism precipitated by an infection of the urinary tract was made. The white cell count was 23,500 per c.mm. with 470 eosinophils/c.mm.; serum sodium was $135 \mathrm{mEq} / 1$., serum potassium $4.5 \mathrm{mEq} / 1$, and blood urea nitrogen $16 \mathrm{mg} . / 100 \mathrm{ml}$. Quantitative urine culture revealed 
the presence of more than 100,000 colonies of Klebsiella aerobacter/ $\mathrm{ml}$. of urine. Plasma cortisol at the height of illness was $8 \mu \mathrm{g}$./ $100 \mathrm{ml}$. (normal 5-20). The patient was treated with penicillin and streptomycin, intravenous fluids, and intramuscular cortisone acetate. Over the course of the next two days the temperature returned to normal, the vomiting and diarrhoea ceased, and the muscle cramps disappeared. In view of this illness it was decided to continue the cortisone in an oral daily dose of $37.5 \mathrm{mg}$.

The patient has been taking cortisone since discharge from the hospital two years ago. He has remained well and has had no further hypoglycaemic attacks.

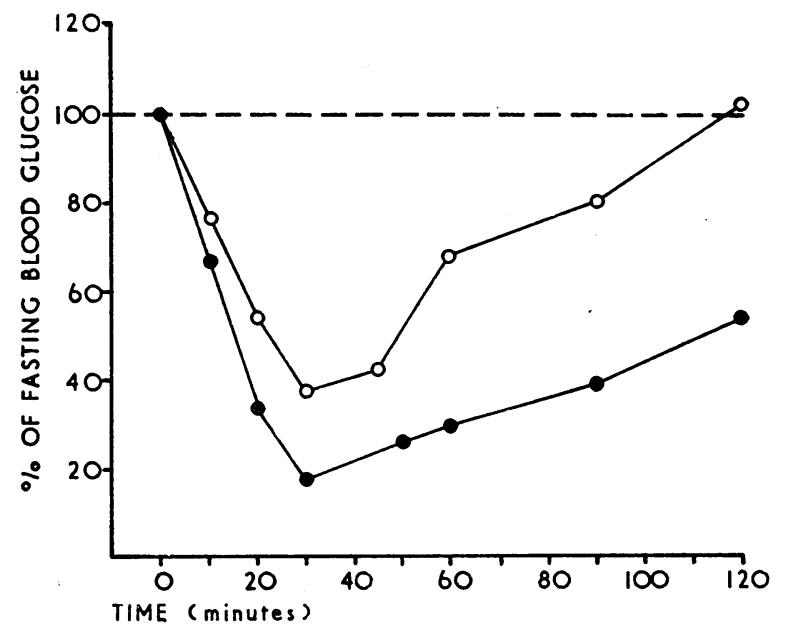

Response to intravenous insulin. 0.1 unit $/ \mathrm{kg}$. given at zero time. $=$ before corticotrophin ; $\mathrm{O}-\mathrm{O}-\mathrm{O}=$ during simultaneous infusion of 40 units of corticotrophin.)

\section{Discussion}

The results of the studies performed in this patient satisfy all the criteria necessary to establish the diagnosis of a functional pituitary or hypothalamic defect affecting the secretion of corticotrophin alone. Urinary gonadotrophins, plasma growth-hormone concentration, and thyroid function studies were all normal. In contrast, urinary excretion of corticosteroids was low. Primary hypoadrenocorticism was excluded by the normal response of the urinary corticosteroids to exogenous corticotrophin. However, no response to the administration of methopyrapone (metyrapone) occurred, indicating that secretion of endogenous corticotrophin was defective. Furthermore, the correction of the hypoglycaemia-unresponsiveness with exogenous corticotrophin (see Fig.) indicated that the unitrophic pituitary defect was in all likelihood responsible for the hypoglycaemic attacks.

The patient's reaction to an acute illness was also consistent with diminished corticotrophin-reserve. Despite clinical manifestations consistent with acute hypoadrenocorticism, no electrolyte changes were observed. The absence of electrolyte changes was probably due to a normal circulating concentration of aldosterone, since the secretion of this hormone is not directly dependent on corticotrophin-secretion.

Growth-hormone deficiency was excluded by the normal response of circulating growth-hormone to hypoglycaemia.
Insulin-induced hypoglycaemia produced an elevation of growth-hormone comparable to that which occurs in normal subjects (Roth et al., 1963).

Though routine thyroid function studies in this patient were normal, the daily disposal of ${ }^{131}$ I-labelled thyroxine was depressed. This abnormality was corrected by the administration of cortisone in physiological dosage. An increase in basal oxygen consumption also occurred after replacement therapy had been begun. The acceleration of thyroxine-disposal was in all likelihood due to the stimulation of metabolism that cortisone induced.

The role of alcohol in this patient's illness is difficult to assess. The earlier episodes of hypoglycaemia might very well have been due to the ingestion of alcohol in the fasting state. However, the subsequent demonstration of a pituitary abnormality that is known to be associated with defective gluconeogenesis could have been responsible for the patient's susceptibility to the hypoglycaemic effect of alcohol. On the other hand, the long-term ingestion of alcohol might itself have impaired the hypothalamic-pituitary mechanism responsible for the secretion of corticotrophin.

\section{Summary}

A case is described of a man who suffered frequent episodes of fasting hypoglycaemia, some of which appeared to be precipitated by alcohol. Studies of endocrine function revealed normal secretion of growth-hormone, thyrotrophin, and gonadotrophin, but deficient secretion of corticotrophin. Hypoglycaemia-unresponsiveness to insulin was corrected by exogenous corticotrophin. An illness precipitated by an infection and resembling acute hypoadrenocorticism occurred and responded promptly to cortisone. Thereafter, cortisone was continued in physiological dosage, and no further hypoglycaemic episodes have occurred.

The studies indicated that a functional hypothalamic or pituitary disorder affecting the secretion of corticotrophin alone was responsible for the hypoglycaemia.

\section{Addendum}

The authors have recently learned of the patient's death. The events during the weeks preceding his death are not altogether clear; his sister states that he began to drink heavily again, stopped taking his medication, and was found dead in his room. A necropsy was not performed; it seems likely that he died as a result of a prolonged hypoglycaemic episode.

This study was supported by U.S.P.H.S. Grant No. 5-MO1-FR0076-01.

\section{REFERENCES}

Bondy, P. K. (1958). Amer. F. Med., 24, 428.

Freinkel, N., Singer, D. L., Arky, R. A., Bleicher, S. J., Anderson, J. B., and Silbert, C. K. (1963). F. clin. Invest., 42, 1112

Liddle, G. W., Island, D., Lance, E. M., and Harris, A. P. (1958). F. clin. Endör. 18, 906

Roth, J., Glick, S. M., Yalow, R. S., and Berson, S. A. (1963). Science, 140, 987. 